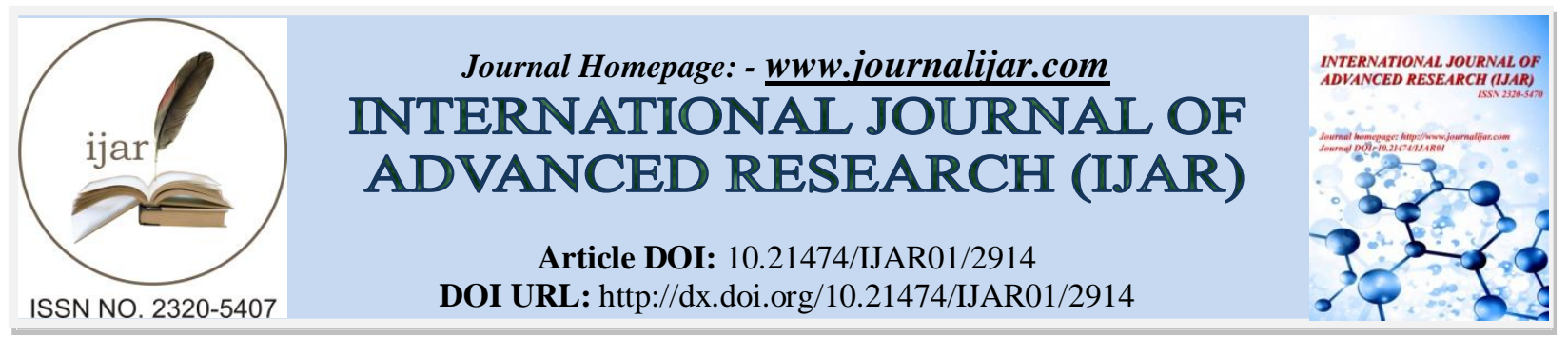

RESEARCH ARTICLE

\title{
ASSESSMENT OF EXISTING PHYSICAL FEATURES OF RURAL KITCHEN IN KANPUR DEHAT.
}

Dr.Kirtima Sachan ${ }^{1}$, Dr. Rekha Dayal ${ }^{2}$ and Dr. Nimisha Awasthi ${ }^{3}$.

1. Ph.D Scholar, Department of FRM, MAB college of Home Science, C.S.A.U.A. \& T., Kanpur.

2. Professor, Department of FRM, MAB college of Home Science, C.S.A.U.A. \& T., Kanpur.

3. Programme Assistant, Department of FRM, MAB college of Home Science, C.S.A.U.A. \& T., Kanpur.

\section{Manuscript Info}

.........................

Manuscript History

Received: 24 November 2016

Final Accepted: 25 December 2016

Published: January 2017

Key words:-

Existing physical feature, Rural kitchen.

\section{Abstract}

Women spent their most of the time in the kitchen. Their work efficiency, cooking quality and the stress on women is more important in the kitchen. All these will be going to affect by physical condition of the kitchen. Compare to bedroom, kitchen rooms, need proper planning of lighting but unfortunately due importance not given to the kitchen. A study was conducted in village area to affect the physical condition of the rural kitchen on the house wives of rural area while carrying out kitchen activities. The study indicated that there is a need to create awareness and educate housewives about the necessity of good physical condition for carrying out cooking activities with ease and comfort and also to impress upon them the unnecessary strain that they under go due to poor physical condition of kitchen. Keeping this fact in view the present study was conceptualized to gain inside into the rural kitchen, its physical features and water facilities. Study was conducted in Kanpur Dehat through direct interview schedule. Rural kitchen were still not in good condition maximum were of kachcha type and constructed in open place.

Copy Right, IJAR, 2016,. All rights reserved.

\section{Introduction:-}

Housing is a basic human need and an important constituent for the quality life of the people and an index of the socio-economic progress of a country. It provides the base for increased access to health, education and sanitation, especially for the poor and the vulnerable groups. Housing in India has two major facets: urban and rural. Urban housing received more attention because of the pressure of growing population and the need to meet the requirements of slum and pavement dwellers as well as urban renewal. In the process, rural housing got neglected, though the greater part of population lives in villages. The nature and magnitude of rural housing problem is much more complex. In the rural areas, poor people usually live in kachcha sheds which can hardly be called houses in the true sense. It is surprising but true that when living standard of people has been rising day by day, there is not much improvement in the organization and qualities of kitchen especially in rural areas and lower income brackets of urban areas. Mud, brick wall and cow dung smeared floor were the most common being found in almost all the houses while only one had stone wall and two had their flooring of cement in Ludhiana (Kirthi, 1985).

Encyclopedia Britannica has defined kitchen "as a room or place in a house for cooking in which culinary and other activities are kept". The kitchen is the most valuable and important place in a house because cooking is done here for the physical and mental fitness of the family members. A family's physical and mental health depends upon the 
food cooked in the kitchen and (Patani, 1979). In other words, kitchen is a very significant part of house. A home maker spends major part of her working hours in food related tasks and the kitchen is the main arena where these tasks are performed. A rural homemaker spends about 6 to 7 hours daily in the kitchen (Sandhu, 1972). It is important that kitchen of a house should meet at least minimal standards, so that the health and safety of a home maker, who spends most of her time in the kitchen can be safe guarded. Hence, careful planning and organization of kitchen are imperative to perform the activities efficiently and reduce the time and energy spent in cooking related activities. Keeping this fact in view the present study was conceptualized to gain inside into the rural kitchen, its physical features, use and storage features available so as to pave the way. Further, it was thought that a study of this nature would also build information on prevalent conditions in rural housing as we entered the new millennium.

\section{Materials and Methods:-}

The study was conducted in Kanpur dehat of Uttar Pradesh during the year 2016. The pre-coded interview schedule was constructed in order to elicit information needed to obtain the objectives of the study. Multistage purposive random sampling technique was followed to select the state, district, blocks, villages and respondents. District Kanpur dehat was purposively selected as a field of study while four blocks namely Akbarpur, Maitha, Amraudha and Rajpur were selected randomly. Two villages from each selected block i.e. Bara and Patari village from Akbarpur block, Chhateni and Tikari villages from Maitha block, Chaprehta and Fattepur village from Amraudha block and from Rajpur block Kandhi and Dewanpur village were selected randomly. Twenty respondents from each selected village were randomly selected. Total 160 respondents were randomly selected for final data collection.

\section{Results and Discussion:-}

The housing as a component of social sector of modern economy was most under developed and under invested. In other words, housing was one such social sector which often exhibited very low yield.

Table 1:- Distributions of Households on the Basis of location of Kitchen.

\begin{tabular}{|c|l|c|c|}
\hline S.No & Location of Kitchen & Frequency & Percentage \\
\hline $\mathbf{1}$ & Verandah & 37 & 23.13 \\
\hline $\mathbf{2}$ & Open & 90 & 56.25 \\
\hline $\mathbf{3}$ & Close Compact & 33 & 20.62 \\
\hline $\mathbf{4}$ & Total & $\mathbf{1 6 0}$ & $\mathbf{1 0 0 . 0 0}$ \\
\hline
\end{tabular}

Results of the study in table 1 revealed that Area used for cooking food is mentioned as kitchen in the study. Data pertinent to physical features of rural kitchen presented in table 4.2.1 inferred that majority (56.25\%) households had open kitchen while about twenty four per cent kitchens were located in verandah, followed by 20.63 per cent kitchens were close compact kitchen, whereas data pertinent to location of cooking area as identified by Awasthi $\boldsymbol{e t}$ al. (2002) revealed that while $50.83 \%$ rural families carried out cooking in a separate/enclosed kitchen the remaining cooked in open varandah or backyard.

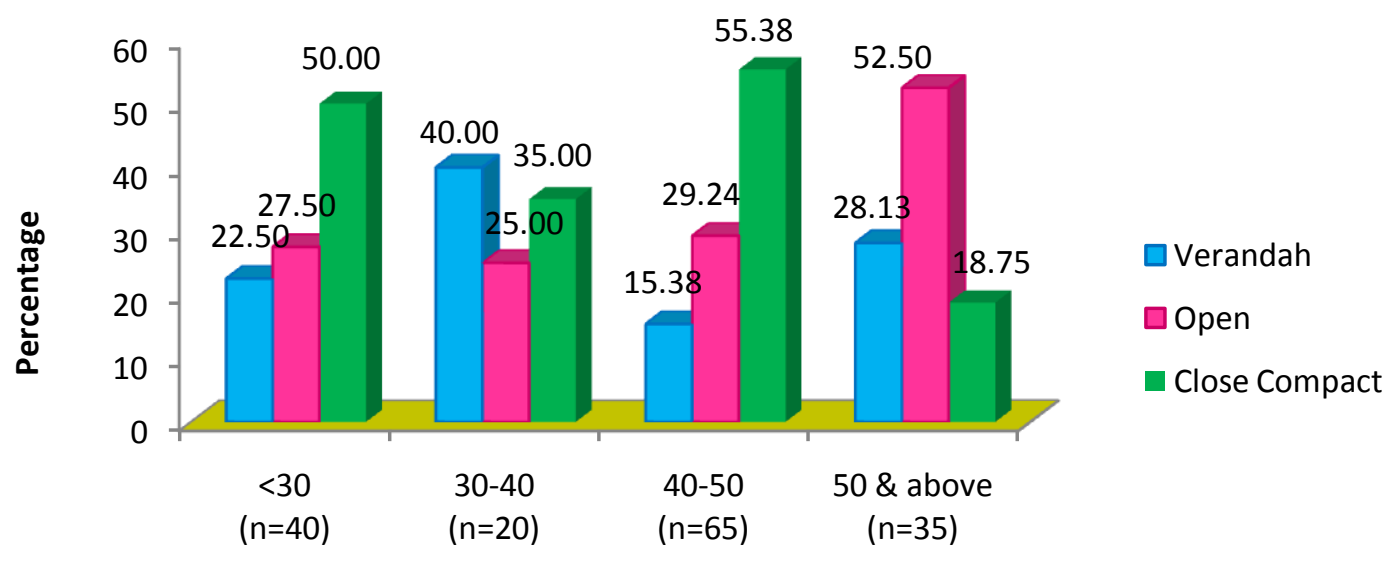

Age Group (years)

Fig 1.2:- Location of Kitchen According to the Age of Respondents 
Clearly depicts that maximum respondents belonging to less than thirty year of age group were having close compact kitchen but in contrast to this majority of fifty and above age groups respondents were having open kitchen. Majority of respondents having kitchen in verandah were belonging to 30-40 years of age.

Table 2:- Distribution of Households on the Basis of Orientation of Kitchen

\begin{tabular}{|c|l|c|c|}
\hline S.No & Orientation of Kitchen & Frequency & Percentage \\
\hline $\mathbf{1}$ & East & 50 & 31.25 \\
\hline $\mathbf{2}$ & West & 45 & 28.13 \\
\hline $\mathbf{3}$ & North & 25 & 15.62 \\
\hline $\mathbf{4}$ & South & 40 & 25.00 \\
\hline & Total & $\mathbf{1 6 0}$ & $\mathbf{1 0 0 . 0 0}$ \\
\hline
\end{tabular}

As per the recommendations given by R.S. Deshpande (1965) kitchen should be oriented towards East or Northeast and about thirty one per cent households were having their kitchen towards East side followed by 28.13 per cent who's kitchen had West orientation. One quarter kitchens were oriented towards South, whereas minimum (15.62 $\%)$ kitchens were having North orientation.

Table 3:- Distribution of Households on the Basis of Style of the Kitchen.

\begin{tabular}{|c|l|c|c|}
\hline S.No & Style of the Kitchen & Frequency & Percentage \\
\hline $\mathbf{1}$ & Sitting & 120 & 75.00 \\
\hline $\mathbf{2}$ & Standing & 25 & 15.62 \\
\hline $\mathbf{3}$ & Sitting \& standing both & 15 & 9.38 \\
\hline & Total & $\mathbf{1 6 0}$ & $\mathbf{1 0 0 . 0 0}$ \\
\hline
\end{tabular}

Out of total 160 households, three fourth i.e. 75.00 per cent households under the study were having sitting style kitchen, while 15.62 per cent households were having standing kitchens. Only nine per cent households were found to have sitting and standing both styles as per the need.

Table 4: Distribution of Households on the Basis of Type of Kitchen

\begin{tabular}{|c|l|c|c|}
\hline S.No & Type of Kitchen & Frequency & Percentage \\
\hline $\mathbf{1}$ & Kachcha & 40 & 25.00 \\
\hline $\mathbf{2}$ & Mixed & 85 & 53.13 \\
\hline $\mathbf{3}$ & Pucca & 35 & 21.87 \\
\hline & Total & $\mathbf{1 6 0}$ & $\mathbf{1 0 0 . 0 0}$ \\
\hline
\end{tabular}

More than fifty per cent households were having mixed type of kitchen followed by twenty five per cent who had kachcha type of kitchen. About twenty two per cent kitchens were pucca kitchens.

Table 5:- Distribution of Households on the Basis of Type of Floor

\begin{tabular}{|c|l|c|c|}
\hline S.No & Type of Floor & Frequency & Percentage \\
\hline $\mathbf{1}$ & Mud & 81 & 50.63 \\
\hline $\mathbf{2}$ & Brick & 37 & 23.12 \\
\hline $\mathbf{3}$ & Cement plastered & 33 & 20.62 \\
\hline $\mathbf{4}$ & Tiled/Mosaic & 9 & 5.63 \\
\hline & Total & $\mathbf{1 6 0}$ & $\mathbf{1 0 0 . 0 0}$ \\
\hline
\end{tabular}

More than fifty per cent floors out of total kitchen under the study were made of mud, followed by 23.12 per cent which were made of bricks. About twenty one per cent kitchen floors were cement plastered. Minimum i.e. only about six per cent kitchen floors were made of tiles or mosaic.

Table 6:- Distribution of Households on the Basis of Kitchen Enclosures

\begin{tabular}{|c|l|c|c|}
\hline S.No & Kitchen Enclosures & Frequency & Percentage \\
\hline $\mathbf{1}$ & With roof \& dwarf wall & 35 & 21.88 \\
\hline $\mathbf{2}$ & Roof with high wall & 33 & 20.62 \\
\hline $\mathbf{3}$ & Without roof \& dwarf wall & 29 & 18.13 \\
\hline $\mathbf{4}$ & With roof \& without dwarf wall & 63 & 39.37 \\
\hline & Total & $\mathbf{1 6 0}$ & $\mathbf{1 0 0 . 0 0}$ \\
\hline
\end{tabular}


As per the table 6 majority (39.37\%) households having kitchen without roof and dwarf wall, whereas 21.88 per cent kitchens were enclosed with roof and dwarf wall. Further 20.62 per cent kitchens were having roof with high walls while, about eighteen per cent kitchens were enclosed by roof but not having dwarf wall.

Table 7:- Distribution of Households on the Basis of Construction Material of Roof

\begin{tabular}{|c|l|c|c|}
\hline S.No & Construction Material of Roof & Frequency & Percentage \\
\hline $\mathbf{1}$ & Thatch & 13 & 8.13 \\
\hline $\mathbf{2}$ & Fired mud tiles & 28 & 17.50 \\
\hline $\mathbf{3}$ & Tin shade & 15 & 9.38 \\
\hline $\mathbf{4}$ & Brick & 18 & 11.25 \\
\hline $\mathbf{5}$ & Cemented plastered & 23 & 14.37 \\
\hline & Total & $\mathbf{1 6 0}$ & $\mathbf{1 0 0 . 0 0}$ \\
\hline
\end{tabular}

Roof was found in 97 kitchens and out of those maximum i.e. about eighteen per cent roofs were made of fired mud tiles, while 14.37 per cent households were having cement plastered roofs in their kitchen followed by 11.25 per cent households were having roofs of kitchen made of bricks. About ten per cent households were having tin shade on kitchen. Only 8.13 per cent were having thatched roof. Majority about thirty nine per cent kitchens were not having any roof.

Table 8:- Distribution of Households on the Basis of Construction Material of Wall.

\begin{tabular}{|c|l|c|c|}
\hline S.No & Construction Material of Wall & Frequency & Percentage \\
\hline $\mathbf{1}$ & Mud & 43 & 26.88 \\
\hline $\mathbf{2}$ & Brick & 29 & 18.13 \\
\hline $\mathbf{3}$ & Plastered & 25 & 15.62 \\
\hline $\mathbf{4}$ & No construction of wall & 63 & 39.37 \\
\hline & Total & $\mathbf{1 6 0}$ & $\mathbf{1 0 0 . 0 0}$ \\
\hline
\end{tabular}

Out of total 97 households having walls in their kitchen, 26.88 per cent households were having mud walls in their kitchens, while more than eighteen per cent households were having brick walls in the kitchen. About sixteen per cent households were having cement plastered walls in the kitchen. On the other hand 39.37 per cent households were not having any walls in their kitchens.

\section{Conclusions:-}

The outcomes of the study reveals that $20.62 \%$ respondents carried out cooking in a separate or closed compact kitchen while $23.13 \%$ of them cooked in verandah and majority $56.25 \%$ respondents cooked food in open place of the house. $28.13 \%$ kitchens had west oriented face. More interestingly, only $42.5 \%$ rural kitchen had roof and out of those only $14.35 \%$ were cement plastered roof. Hence, it can be concluded that the kitchens in rural areas are in poor conditions compare to urban areas. Therefore, rural kitchens and its designing need immediate attention of planners, policy makers' architects and builders apart from households themselves.

\section{References:-}

1. Awasthi, N. (2002) Assessment of physical features and quality of rural kitchen unpublished. M.Sc. Thesis, C.S.A. University of Agri. and Tech., Kanpur. 137 p.

2. Deshpande, R.S. 1965. Grouping and Synthesis of a Home. Modern Ideal Houses for India pp. 44-47.

3. Kirthi, 1985, A study of the Condition of Rural Kitchen Journal of Research 20 (2): 131-135.

4. Patani, M. 1979, Kitchen Griha Prabhandha Awash Evam Griha Sajja, IInd ed. Published by Star Publication Agra, pp. 99-101.

5. Sandhu, M.K., 1972 A study of the utilization of the time spent in performing household activities by the home makers in rural area Kurukshetra Indian journal for village Development Govt.of India 16(3). 511-516. 